\title{
Concurrent emergence of exotic whitefly incursions on arecanut (Areca catechu L.) in India
}

\author{
Shivaji Hausrao Thube*, A. Josephrajkumar ${ }^{1}$, R. Thava Prakasa Pandian, \\ E.K. Saneera, Bhavishya, Merin Babu', Rajkumar ${ }^{2}$ and C.T. Jose \\ ICAR-Central Plantation Crops Research Institute, Regional Station, Vittal-574 243, Karnataka, India \\ ${ }^{I}$ ICAR-Central Plantation Crops Research Institute Regional Station, Kayamkulam-690 533, Kerala, India \\ ${ }^{2}$ ICAR-Central Plantation Crops Research Institute, Kasaragod-671 124, Kerala, India
}

(Manuscript Received: 07-10-2020, Revised: 08-03-2021, Accepted: 12-03-2021)

\begin{abstract}
Field incidence of exotic whitefly complex comprising two Neotropical nesting whiteflies viz., Paraleyrodes bondari Peracchi and Paraleyrodes minei Iaccarino, in association with invasive rugose spiralling whitefly Aleurodicus rugioperculatus Martin and native areca whitefly, Aleurocanthus arecae David \& Manjunatha, on arecanut was reported from Karnataka, India during 2020. These arecanut palms were previously infested by $A$. arecae which was earlier reported from Karnataka during 2003 . To our knowledge, this is the first report on the infestation of $P$. bondari and $P$. minei on arecanut as highlighted in this current investigation. Morphological identification based on pupal taxonomy and male genitalia as well as molecular characterization of the mitochondrial cytochrome oxidase I ( $C O I)$ gene confirmed the identity of nesting whiteflies. The Bondar's nesting whitefly, P. bondari is the most predominant whitefly species with 87.5 per cent active colonies followed by the nesting whitefly, $P$. minei (13.64\%) and the rugose spiralling whitefly, A. rugioperculatus (6.25\%). Co-occurrence of these three non-native whitefly species on arecanut in synergy with the native $A$. arecae indicates a kind of competitive regulation of one species over the other, upsetting biodiversity. Due to the polyphagous nature of the pest coupled with increased trade and transport in a climate change scenario, this whitefly complex may become a serious threat to arecanut production in India and elsewhere. This requires strict quarantine protocols to avert its spread to other arecanut growing areas.
\end{abstract}

Keywords: Arecanut, biosecurity, nesting whiteflies, rugose spiralling whitefly

\section{Introduction}

Whiteflies belong to the family Aleyrodidae and are considered as an economically important polyphagous sucking pest of Hemiptera (Sundararaj and Dubey, 2019). Adults resemble small moths, with about 1550 species described across the globe (Ouvrard and Martin, 2018). They are the key pests of important agricultural and horticultural crops. They damage crops in three different ways viz., by direct sap-feeding, as vectors of plant diseases or indirectly affecting the photosynthesis by deposition of sooty mould on plants through honeydew production (David, 2012). Primarily they colonize dicots, but a few of them feed on monocots as well, mostly on grasses and palms (Martin et al., 2000).
Till now, around 440 species of whiteflies belonging to 63 genera are reported from India (Sundararaj et al., 2018). Around 320 species of plants under 225 genera and 73 families within India have been recorded as alternate hosts of whiteflies (Sundararaj and Pushpa, 2011).

Invasion of exotic pests in a non-native environment poses a big challenge due to the nonexistence of their natural limiting factors during the initial phase of introduction. In the recent past, slackening of the international trade and frequent exchanging of the planting material between the various countries has increased the chances for accidental entry of several exotic pests. Recently, India has witnessed the incursion of exotic whiteflies

*Corresponding Author: shivajithube@gmail.com 
such as the solanum whitefly, Aleurotrachelus trachoides (Dubey and Sundararaj, 2015), rugose spiralling whitefly Aleurodicus rugioperculatus Martin (Shanas et al., 2016), Bondar's nesting whitefly Paraleyrodes bondari Peracchi (Josephrajkumar et al., 2019), Nesting whitefly Paraleyrodes minei (Chandrika et al., 2019; Dubey, 2019) and palm whitefly Aleurotrachelus atratus (Selvaraj et al., 2019). Within a short period after its introduction, RSW expanded its host range exponentially and reported on many horticultural crops like guava, jamun, teak and tropical almond etc. (Chandrika et al., 2017; Chakravarthy et al., 2017). A total of 21 plant species belonging to 15 families were recorded as hosts of RSW (Elango et al., 2019). The polyphagous and invasive nature of this pest is a big concern to farmers specifically on crops like guava, coconut, eucalyptus and citrus from India (Josephrajkumar et al., 2019).

Though earlier reports recorded the incidence of $A$. arecae and $A$. rugioperculatus on arecanut, the present investigations added arecanut as a new host record for $P$. bondari and $P$. minei. Detailed morphological and molecular characterization of all the three invasive species has been carried out. As the three species of whiteflies co-existed during the investigation, the relative dominance of these nonnative whiteflies on arecanut is also presented in the manuscript.

\section{Materials and methods}

\section{Sampling site}

Whiteflies infested leaves of arecanut palms were first collected from Moodabidri, Karnataka $\left(13.3412^{\circ} \mathrm{N}, 74.54807^{\circ} \mathrm{E}\right)$ during September 2020. Symptoms of the infestation were recorded systematically. Insect samples collected from the fields were further subjected to morphological and molecular characterization.

\section{Morphological characterization}

Insect colonies on the collected leaf samples were observed under a microscope for their egglaying pattern, life stages and colony structure. A Leica stereomicroscope M10, equipped with an EC4 Digital Camera was used for imaging pupal and adult taxonomic features and subsequent identification of various species. As puparia and male genitalia play an important role in the identification of P. bondari and P. minei, permanent slide mounts of the pupae and the male genitalia were prepared and observed under a compound microscope (Leica DMLB2) (Martin, 2004).

\section{Molecular characterization}

Since molecular characterization proved a supportive tool for the identification of nesting whiteflies, adult specimens identified by morphological characteristics were further subjected to molecular characterization using the mitochondrial cytochrome c oxidase I ( $m t C O I)$ gene. The genomic DNA was extracted by the standard protocol using the CTAB method.

PCR reactions were performed to amplify the partial $m t C O I$ gene with a $25 \mu \mathrm{L}$ reaction volume containing $4.0 \mu \mathrm{L}$ of $10 \mathrm{X}$ Buffer, $1.0 \mu \mathrm{L}$ of dNTPs, $1.0 \mu \mathrm{L}$ each of forward (LCO1490 5'-GGTCAA CAAATCATAAAGATATTGG-3') and reverse (HCO2198 5'-TAAACTTCAGGGTGACCAAA AAA TCA-3') primers (Folmer et al., 1994) (10 pmol mL $\left.\mathrm{mL}^{-1}\right), 1.0 \mu \mathrm{L}$ of Taq polymerase, $1.0 \mu \mathrm{L}$ of genomic DNA and $16.0 \mu \mathrm{L}$ of molecular grade water. Thermocycling (Bio-Rad T100) consisted of an initial denaturation at $94^{\circ} \mathrm{C}$ for $3 \mathrm{~min}$, followed by 30 cycles of denaturation at $94^{\circ} \mathrm{C}$ for $20 \mathrm{sec}$, annealing at $50^{\circ} \mathrm{C}$ for $30 \mathrm{sec}$, extension at $72^{\circ} \mathrm{C}$ for $30 \mathrm{sec}$, and final extension at $72^{\circ} \mathrm{C}$ for $5 \mathrm{~min}$ (Thube et al., 2018). The amplified product was analyzed with electrophoresis using a 1.0 per cent agarose gel (Sambrook and Russell, 2001). Purified PCR products (Geneaid Biotech Ltd., Taiwan) were sent for Sanger sequencing (Agrigenome Pvt. Ltd., Kochi, India). Sequence similarity was analyzed by aligning our sequence along with available sequences in the National Center for Biotechnology Information (NCBI) (www.ncbi.nlm.nih.gov) and Barcode of Life Data database (www.boldsystems.org) using biological sequence alignment editor (BioEdit). Consensus sequences were submitted in GenBank, NCBI.

\section{Survey on distribution and colonization}

The survey was conducted in various taluks of Dakshina Kannada district viz., Moodabidri, Sullia, Puttur, Bantwal and Belthangady, to know the distribution pattern and species dominance of exotic whiteflies in the arecanut ecosystem. Observation 
on age, variety and status (healthy/diseased) of the infested palms were collected. Colonization studies were conducted based on the infested samples/ leaflets collected from Moodabidri. A total of fifty arecanut leaflets were observed from each location for the presence of species-wise active colonies (Presence of all life stages). Percentage of active colonies of individual species was calculated as follows:

\section{Results and discussion}

$\begin{aligned} & \text { Per cent of colonies } \\ & \text { of individual species }\end{aligned}=\frac{\begin{array}{c}\text { Colonies of individual } \\ \text { species per 50 leaflets }\end{array}}{\begin{array}{c}\text { Total colonies of all species } \\ \text { per } 50 \text { leaflets }\end{array}} \times 100$

Symptoms of the infestation were characterized by the presence of conspicuous sooty mould fungus on the upper side of infested leaflets (Fig. 1a). The lower surface of the infested leaflets witnessed the presence of $A$. arecae intermingled with colonies of nesting whitefly (Fig. 1b).

\section{Morphological identity}

Infestation of the native arecanut whitefly, $A$. arecae and rugose spiralling whitefly, A. rugioperculatus on arecanut has been already reported from India. Apart from these whiteflies, infestation by two exotic nesting whiteflies
( $P$. bondari and $P$. minei) were also recorded during present investigations and were morphologically identified based on the following characteristic.

\section{Paraleyrodes bondari Peracchi}

Presence of whitish, powdery and compactly constructed nests (Fig. 2a); stalked and elongated eggs (Fig. 2b); flat and oval nymphs with the presence of marginal waxy filaments (Fig. 2c); the presence of flat pupa with six pairs of compound pores at the caudal end and one pair at the cephalic end in tightly constructed colonies (Fig. 2d); small adult measuring about $1.1 \mathrm{~mm}$ with typical $\mathrm{X}$-shaped markings on wings (Fig. 2e) and rod-like male genitalia with anterior and posterior horns (Fig. 2f).

\section{Paraleyrodes minei Iaccarino}

Morphologically, Paraleyrodes minei is distinguished from $P$. bondari based on the following characters.

Presence of whitish, silken and loosely constructed nests (Fig. 3a); the existence of flat pupa with six pairs of compound pores at the caudal end and one pair at the cephalic end in loosely constructed colonies (Fig. 3b); white coloured small adult measuring about $1.2 \mathrm{~mm}$ devoid of any marking on wings (Fig. 3c) and typical cock-head like male genitalia (Fig. 3d).
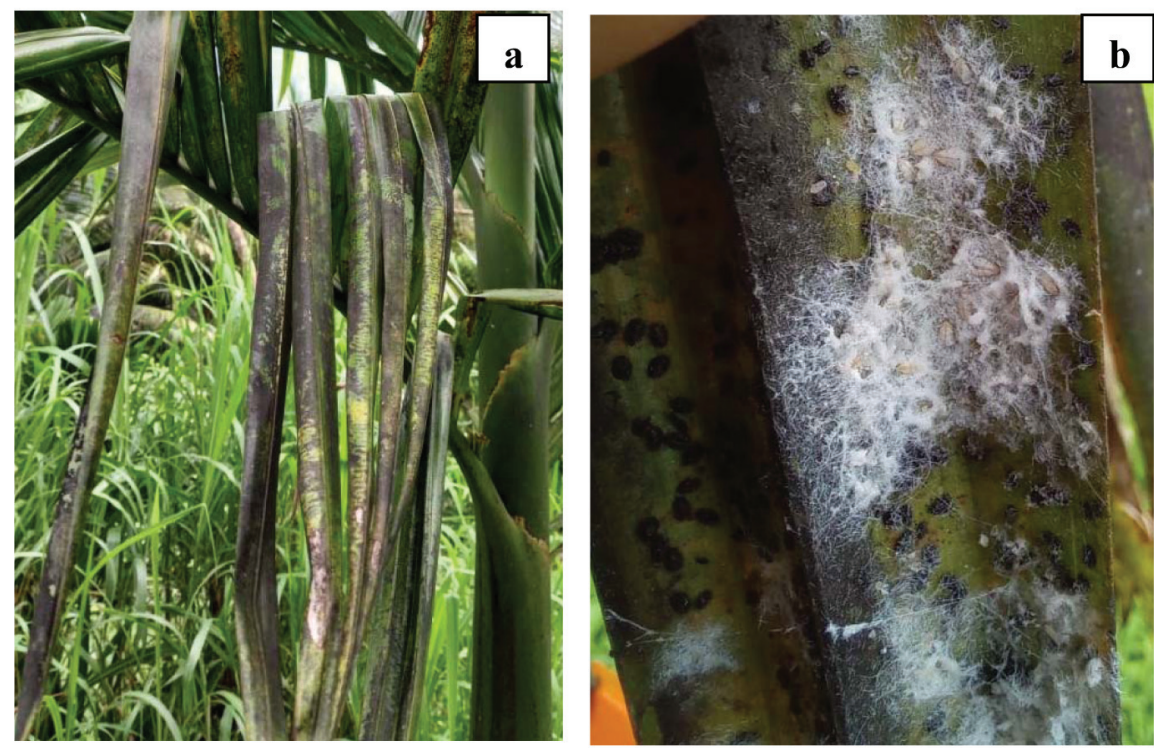

Fig. 1. Damaging symptoms a. Presence of sooty mould fungus, b. Whitefly colonies 

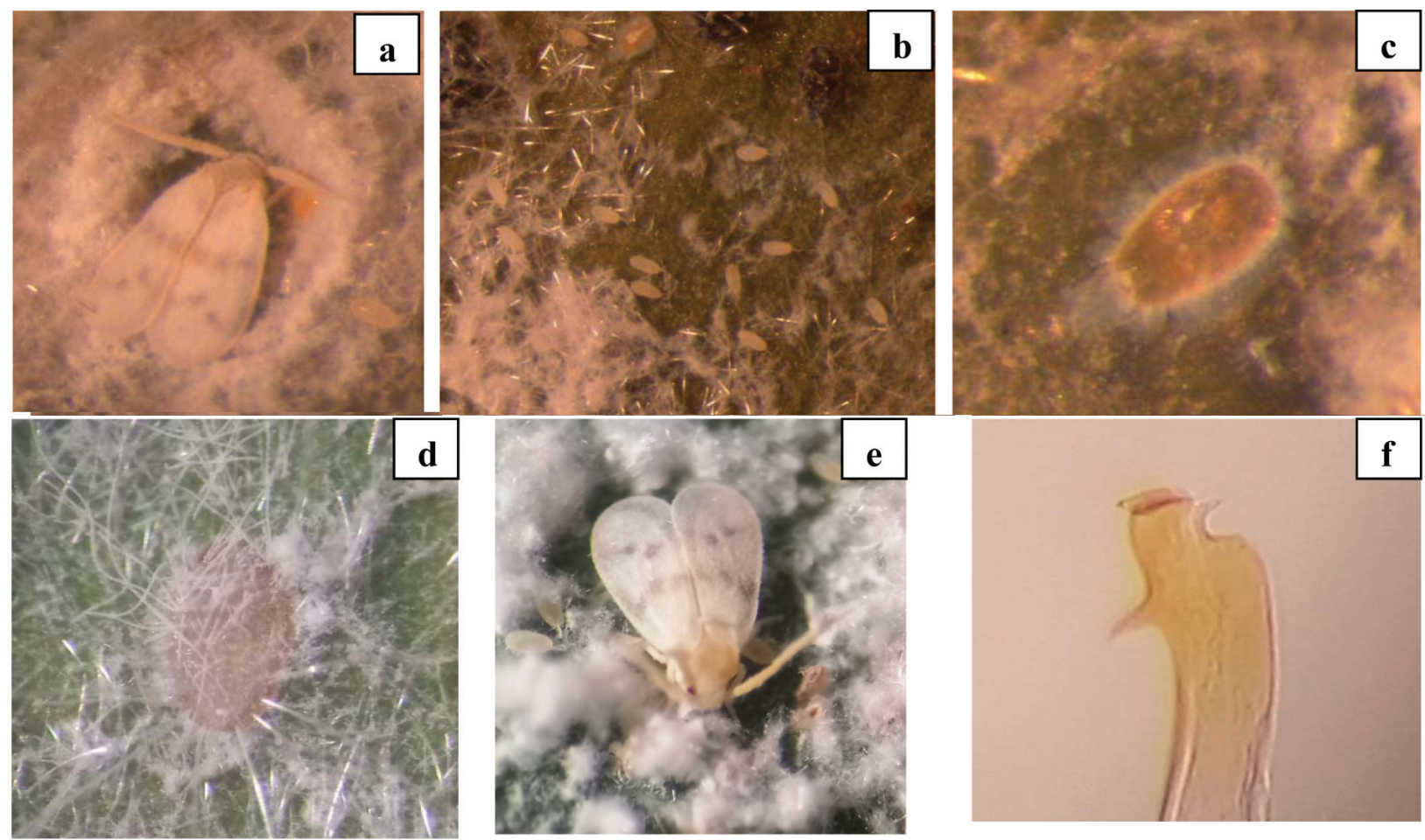

Fig. 2. Paraleyrodes bondari a. Colony, b. Eggs, c. Nymph, d. Pupa, e. Adult, f. Male genitalia

\section{Molecular identification}

Molecular characterization of the A. rugioperculatus, $P$. bondari and P. minei was confirmed by amplifying and sequencing the 687 , 684 and 683 bp of the $m t C O I$ gene, respectively. The nucleotide sequences of the $m t C O I$ gene of these exotic whiteflies submitted to GenBank (accession number MW041900, MW041899 and MW047062) showed 100 per cent similarity with that of $A$. rugioperculatus, $P$. bondari and $P$. minei (GenBank accession Nos. MK159733.1,
MK343480.1 and MK776865.1) infesting coconut in Peninsular India.

Critical observations of key taxonomic characters including partial features, male genitalia and molecular characterization confirmed the occurrence of two nesting whiteflies, $P$. bondari and P. minei on arecanut for the first time in India. The voucher specimens of all these species are maintained at ICAR-Central Plantation Crops Research Institute Regional Station, Vittal, Karnataka.
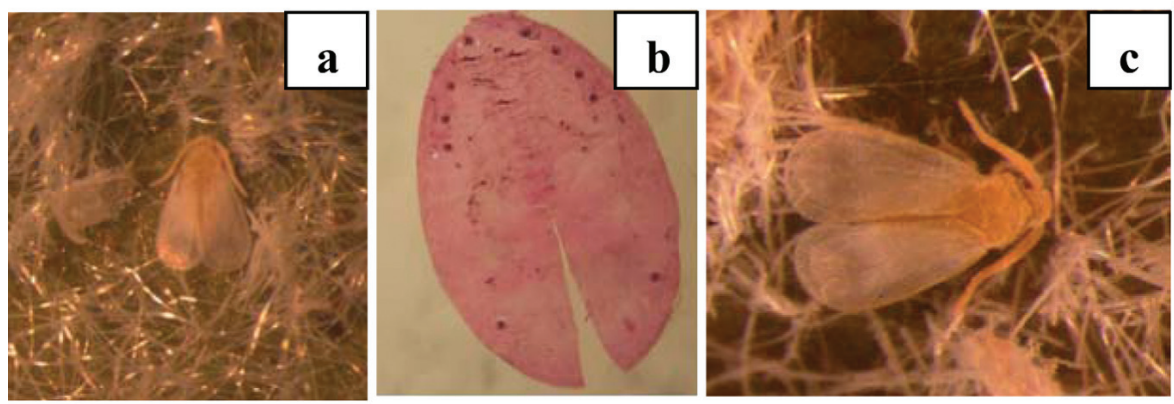

Fig. 3. Paraleyrodes minei a. Colony, b. Pupa, c. Adult, d. Male genitalia 
Table 1. Distribution of invasive whiteflies on arecanut in Dakshina Kannada district of Karnataka

\begin{tabular}{|c|c|c|c|c|c|}
\hline \multirow[b]{2}{*}{ Village } & \multicolumn{2}{|c|}{ GPS coordinates } & \multirow[t]{2}{*}{ Variety } & \multirow{2}{*}{$\begin{array}{c}\text { Age of palms } \\
\text { (Years) }\end{array}$} & \multirow[t]{2}{*}{ Whitefly species } \\
\hline & Latitude & Longitude & & & \\
\hline Moodabidri & $13^{\circ} 34.12^{\prime}$ & $74^{\circ} 54.807^{\prime}$ & Mohitnagar & 3 & $\begin{array}{l}\text { P. bondari, } P \text {. minei } \\
\text { A. rugioperculatus }\end{array}$ \\
\hline Sullia & $\begin{array}{l}12^{\circ} 35.936^{\prime} \\
12^{\circ} 31.421^{\prime}\end{array}$ & $\begin{array}{l}75^{\circ} 28.203^{\prime} \\
75^{\circ} 28.304^{\prime}\end{array}$ & $\begin{array}{l}\text { Mangala } \\
\text { Mangala }\end{array}$ & 2 & P. minei \\
\hline Vittal & $12^{\circ} 46.43^{\prime}$ & $75^{\circ} 06.58^{\prime}$ & VTLAH-2 (Hybrid) & 4 & P. minei \\
\hline Belthangady & $12^{\circ} 50.56^{\prime}$ & $75^{\circ} 17.19^{\prime}$ & Mohitnagar & 3 & P. minei \\
\hline Markanja & $\begin{array}{l}12^{\circ} 34.326^{\prime} \\
12^{\circ} 34.241^{\prime}\end{array}$ & $\begin{array}{l}75^{\circ} 29.861^{\prime} \\
75^{\circ} 29.012^{\prime}\end{array}$ & $\begin{array}{l}\text { SK Local } \\
\text { SK Local }\end{array}$ & $\begin{array}{l}3 \\
2\end{array}$ & $\begin{array}{l}\text { P. minei } \\
\text { P. minei }\end{array}$ \\
\hline
\end{tabular}

\section{Distribution and colonization}

Infestation of all the three invasive whiteflies was recorded on arecanut from Moodabidri taluk of Dakshina Kannada district. Taluk-wise species distribution of these whiteflies is given in Table 1. Though, the occurrence of $P$. minei is recorded from Sullia, Vittal, Belthangady and Markanja, the intensity of infestation was very low (1-2 colonies per leaflet).

Analysis of species dominance indicated Bondar's nesting whitefly, $P$. bondari as the most predominant whitefly species with 87.5 per cent active colonies (Fig. 4)

The arecanut plantation located in Moodubidri taluk that recorded all whiteflies species was surrounded by forest. The co-existence of various species of whiteflies could be due to favourable micro/macro climatic factors and/or a possible migration from unknown alternate forest host trees nearby. Recently, the incidence of RSW and nesting whiteflies were reported on coconut from India (Shanas et al., 2016; Josephrajkumar et al., 2019; Chandrika et al., 2019). As coconut and arecanut belong to the same family, these whiteflies could have extended their host range to arecanut as well.

Though the distribution of $P$. minei is reported from all the area surveyed, the intensity of infestation was very low (1-2 colonies per leaflet). The lower incidence could be attributed to the presence of natural limiting factors preventing its population build up on arecanut. Exploration of these natural limiting factors including bio-agents

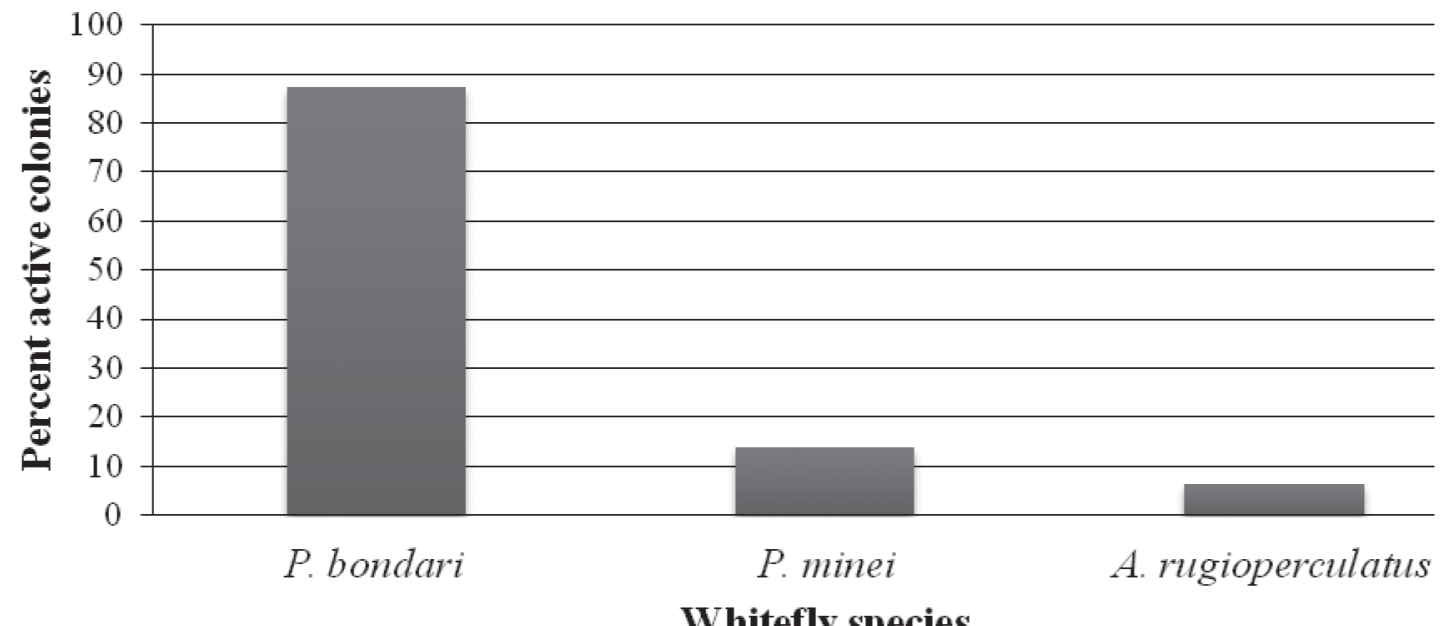

Fig. 4. Species dominance of invasive whiteflies in arecanut 
could be important to develop sustainable management tactics for effective suppression of these invasive whiteflies. Furthermore, the arecanut plantations infested by $P$. minei was found to be infected by leaf spot disease as well. Hence, the weakening of arecanut palms by leaf spot disease would have created a favourable environment for the development of nesting whiteflies. Incidence of these whiteflies on juvenile arecanut plantation aged about 2-3 years could be due to the availability of succulent leaves for feeding and multiplication.

Arecanut is an important commercial plantation crop grown in the southern part of India. If this invasive whitefly population flares up in the arecanut plantation, it would bring forth a great impact on the economy of arecanut growers. Hence, there is a need to evolve efficient management strategies with an emphasis on exploration and conservation of native natural enemies associated with this pest complex.

\section{Conclusion}

Present investigations recorded arecanut as a new alternate host for two exotic nesting whiteflies, $P$. bondari and P. minei. Four whitefly species viz., $A$. arecae, $A$. rugioperculatus, $P$. bondari and $P$. minei co-existed to form a species complex and also preferred juvenile arecanut plantation. In the climate change scenario, Bondar's nesting whitefly, $P$. bondari will be the most dominant whitefly in the arecanut ecosystem. There is a need to evolve efficient management strategies with greater emphasis on biological control to tackle the pest complex to accomplish an environmentally responsible world.

\section{Acknowledgements}

Authors thank the Indian Council of Agricultural Research, New Delhi for the grant in aid through ICAR-CPCRI, Kasaragod, Institutional Project and all the farmers who had generously allowed arecanut leaf sampling from their plantation. The senior author also acknowledges the assistance rendered by Sri. Santhosh Kumar Paichal (Senior Technical Assistant) during the sample collection.

\section{References}

Chakravarthy, A.K., Kumar, K.P., Sridhar, V., Prasannakumar, N.R., Nitin, K.S., Nagaraju, D.K., Shashidhara, G.C., Sudhakara, T.M., Chandrashekar, G.S. and Reddy, P.V.R. 2017. Incidence, hosts and potential areas for invasion by rugose spiraling whitefly, Aleurodicus rugioperculatus Martin (Hemiptera: Aleyrodidae) in India. Pest Management in Horticultural Ecosystems 23(1): 41-49.

Chandrika, M., Josephrajkumar, A., Merin, B., Prathibha, P.S., Krishnakumar, V., Vinayaka H. and Chowdappa, P.2017. Invasive Rugose Spiralling Whitefly on Coconut. Technical Bulletin No. 117, Centenary series 60, pp16. ICAR-CPCRI, Kasaragod.

Chandrika, M., Josephrajkumar, A., Merin, B., Krishna, A., Prathibha, P.S., Krishnakumar, V. and Vinayaka Hegde. 2019. Non-native neotropical nesting whitefly, Paraleyrodes minei Iaccarino on coconut palms in India and its co-existence with Bondar's nesting whitefly, Paraleyrodes bondari Peracchi. Current Science 117(3): 515-519. doi: 10.18520/cs/v117/i3/515-519.

David, V. 2012. The Whitefly or Mealywing Bugs-Bio-ecology, Host Specificity and Management. LAP Lambert Academic Publishing Gmbh\& Co, KG, Germany, 411 p.

Dubey, A. K. 2019. Paraleyrodes minei Iaccarino (Hemiptera: Aleyrodidae)-A new invasive pest threat to Andaman and Nicobar Islands, India. Phytoparasitica 47: 333-339.

Dubey, A. K. and Sundararaj, R. 2015. A new combination and first record of the genus Aleurothrixus Quaintance \& Baker (Hemiptera: Aleyrodidae) from India. Biosystematica 9(1\&2): 23-28.

Elango, K., Nelson, S. J., Sridharan, S., Paranidharan, V. and Balakrishnan, S. 2019. Biology, distribution and host range of new invasive pest of India coconut rugose spiralling whitefly, Aleurodicus rugioperculatus Martin in Tamil Nadu and the status of its natural enemies. International Journal of Agriculture Sciences 11( 9): 8423-8426.

Folmer, O., Black, M., Hoeh, W., Lutz, R. and Vrijenhoek, R. (1994). DNA primers for amplification of mitochondrial cytochrome c oxidase subunit I from diverse metazoan invertebrates. Molecular Marine Biology and Biotechnology 3(5): 294-299.

Josephrajkumar, A., Mohan, C., Babu, M., Krishna, A., Krishnakumar, V., Hegde, V. and Chowdappa, P. 2019. First record of the invasive Bondar's nesting whitefly, Paraleyrodes bondari Peracchi on coconut from India. Phytoparasitica 47(3): 333-339.

Martin, J.H. 2004. Whiteflies of Belize (Aleyrodidae: Hemiptera).Part I- Introduction and account of the subfamily Aleurodicinae Quaintance \& Baker. Zootaxa 681: 1-113.

Martin, J.H., Mifsud, D. and Rapisarda, C. 2000. The whiteflies (Hemiptera: Aleyrodidae) of the Europe and 
the Mediterranean Basin. Bulletin of Entomological Research 90: 407-448.

Ouvrard, D. and Martin, J.H. 2018. The Whiteflies-Taxonomic checklist of the world's whiteflies (Insecta: Hemiptera: Aleyrodidae). https://doi.org/10.5519/0095728 http:// www. hemiptera-databases.org/whiteflies/- searched on 13 December 2018.

Sambrook, J. and Russell, D.W. 2001. Molecular Cloning. A Laboratory Manual (3rd ed.). New York: Cold Spring Harbor Laboratory.

Selvaraj, K., Sundararaj, R. and Sumalatha, B.V. 2019. Invasion of the palm infesting whitefly, Aleurotrachelusatratus Hempel (Hemiptera: Aleyrodidae) in the Oriental region. Phytoparasitica 47: 327-332. https://doi.org/10.1007/ s12600-019-00742-1.

Shanas, S., Joseph, J., Joseph T. and Krishnan, G. 2016. First report of the invasive rugose spiralling whitefly, Aleurodicus rugioperculatus Martin (Hemiptera: Aleyrodidae)from the Old World. Entomon 41(4): 365-368.
Sundararaj, R. and Pushpa, R. 2011. In B. V. David (Ed.), The Whitefly or Mealywing bugs: Bioecology, Host specificity and management (Vol. 2011, pp. 20-57). Germany: Lambert Academic Publishing.

Sundararaj, R. Dubey, A.K. 2019. Invertebrate Diversity and Conservation in the Western Ghats, India. pp. 267 ATREE, Bangalore.

Sundararaj, R., Amuthavalli, T. and Vimala, D. 2018. Invasion and establishment of the solanum whitefly, Aleurothrixus trachoides (Back) (Hemiptera: Aleyrodidae) in South India. Current Science 115(1): 29-31.

Thube, S.H., Mohan, C., Pandian, R.T.P., Saneera, E. K., Sannagoudra, H.M., Hegde, V. and Chowdappa, P. 2018. First Record of the Invasive Neotropical Ambrosia Beetle Euplatypus parallelus (Fabricius, 1801) (Coleoptera: Curculionidae: Platypodinae) Infesting Arecanut in Karnataka, India. The Coleopterists Bulletin 72(4):713-717. 